\title{
Factors Affecting Corrosion in Gulf of Finland Brackish Water
}

\author{
Jari Aromaa and Olof Forsén \\ Department of Materials Science and Engineering, Aalto University, P.O. Box 16200, Aalto, 00076 Espoo, Finland
}

Correspondence should be addressed to Jari Aromaa; jari.aromaa@aalto.fi

Received 29 November 2015; Accepted 26 April 2016

Academic Editor: Grzegorz Milczarek

Copyright (C) 2016 J. Aromaa and O. Forsén. This is an open access article distributed under the Creative Commons Attribution License, which permits unrestricted use, distribution, and reproduction in any medium, provided the original work is properly cited.

\begin{abstract}
The Baltic Sea is a relatively shallow inland sea surrounded by the countries of North-Eastern Europe and Scandinavia. The brackish water in the Baltic Sea has low salt concentration and it is typically one-sixth of the ocean seawater. The "nominal" amount of dissolved solids, upon which formulae for artificial seawater are based, is about $34,500 \mathrm{ppm}$, of which most is sodium chloride. The major constituents are those whose concentrations are greater than $1 \mathrm{mg} / \mathrm{L}$ and are not greatly affected by biological processes. The ratio of concentrations of these ions and molecules to each other is relatively constant. Corrosion rates were determined in longterm tests in Gulf of Finland brackish water off Helsinki. The water temperature varies through the year from about $0^{\circ} \mathrm{C}$ in January to $15-16^{\circ} \mathrm{C}$ in June to August. Salinity is $4-6 \%$, highest at the end of summer and lowest when ice melts. pH is between 7.0 and 8.1 . Weight loss tests from one- to four-year tests for steel, stainless steel, copper, aluminium, zinc, and galvanized steel are reported and compared to short term laboratory tests in artificial seawater. Tests for passivation rates and crevice corrosion for stainless steel are discussed in terms of environment variation. The effect of corrosion on strength of steel is also discussed.
\end{abstract}

\section{Introduction}

Finland is the northernmost member of the European Union and one of the few countries in the world where all harbours are ice-bound during normal winters. The Baltic Sea is a relatively shallow inland sea surrounded by the countries of North-Eastern Europe and Scandinavia. Its total area is about $370,000 \mathrm{~km}^{2}$. Then, mean depth is only $55 \mathrm{~m}$, but the maximum depth reaches down to $459 \mathrm{~m}$. The Baltic Sea is connected to the North Sea through narrow and shallow sounds between Denmark and Sweden. The outlet consists of a series of basins separated by shallow sills, which obstruct efficient water exchange. The environmental conditions of the Baltic Sea are defined by the fresh water input from rivers and precipitation and by the limited inflow of more saline water from the North Sea. The salinity varies from the almost oceanic conditions in the northern Kattegat to the almost fresh water conditions in the Northern Gulf of Bothnia. The most important factors that affect corrosion in cold brackish water are low concentration of dissolved solids, low conductivity, and high concentration of dissolved oxygen.
The "nominal" amount of dissolved solids, upon which formulae for artificial seawater are based, is about $34,500 \mathrm{ppm}$, of which most is sodium chloride. The major constituents are those whose concentrations are greater than $1 \mathrm{mg} / \mathrm{L}$ and are not greatly affected by biological processes. The ratio of concentrations of these ions and molecules to each other is relatively constant. A typical seawater composition, showing major salt constituents, is given in Table 1.

Salinity is the total amount of dissolved salts in seawater in grams/kilograms or parts per thousand. Average ocean salinity is 35 , but salinity ranges from 33 to 37 in the surface waters of the open ocean. Brackish water has a salinity of less than 25 . Salinity is usually determined either by conductivity measurements or from the chlorinity. Chlorinity, in turn, is "the mass in grams of silver required to precipitate the halogens in 0.3285234 kilograms of seawater" [1]. This is nearly equal to the mass of chloride in the seawater sample. Chlorinity (\%o) is related to salinity $S(\%)$ by $S(\%)=1.80655 \cdot \mathrm{Cl}(\%)$. The ions in seawater influence the electrical conductivity of the water. Salinity is not temperature dependent, but conductivity is affected by 
TABLE 1: Concentrations of the most abundant ions and molecules in seawater of $35 \%$ salinity and density $1.023 \mathrm{~g} / \mathrm{cm}^{3}$ at $25^{\circ} \mathrm{C}[1]$.

\begin{tabular}{lccc}
\hline Component & Concentration, mmol/kg & Concentration, g/kg & Wt-\% of total salt \\
\hline Chloride, $\mathrm{Cl}^{-}$ & 545.9 & 19.354 & 55.016 \\
Sodium, $\mathrm{Na}^{+}$ & 468.5 & 10.77 & 30.615 \\
Sulfate, $\mathrm{SO}_{4}{ }^{2-}$ & 28.23 & 2.712 & 7.709 \\
Magnesium, $\mathrm{Mg}^{2+}$ & 53.08 & 1.290 & 3.667 \\
Calcium, $\mathrm{Ca}^{2+}$ & 10.28 & 0.412 & 1.171 \\
Potassium, $\mathrm{K}^{+}$ & 10.21 & 0.399 & 1.134 \\
Bicarbonate, $\mathrm{HCO}_{3}{ }^{-}$ & 2.30 & 0.140 & 0.398 \\
Bromide, $\mathrm{Br}^{-}$ & 0.84 & 0.067 & 0.190 \\
Boric acid, $\mathrm{H}_{3} \mathrm{BO}_{3}$ & 0.416 & 0.0257 & 0.073 \\
Strontium, $\mathrm{Sr}^{2+}$ & 0.09 & 0.008 & 0.023 \\
Fluoride, $\mathrm{F}^{-}$ & 0.07 & 0.0013 & 0.004 \\
Total & 1119.916 & 35.179 & 100 \\
\hline
\end{tabular}

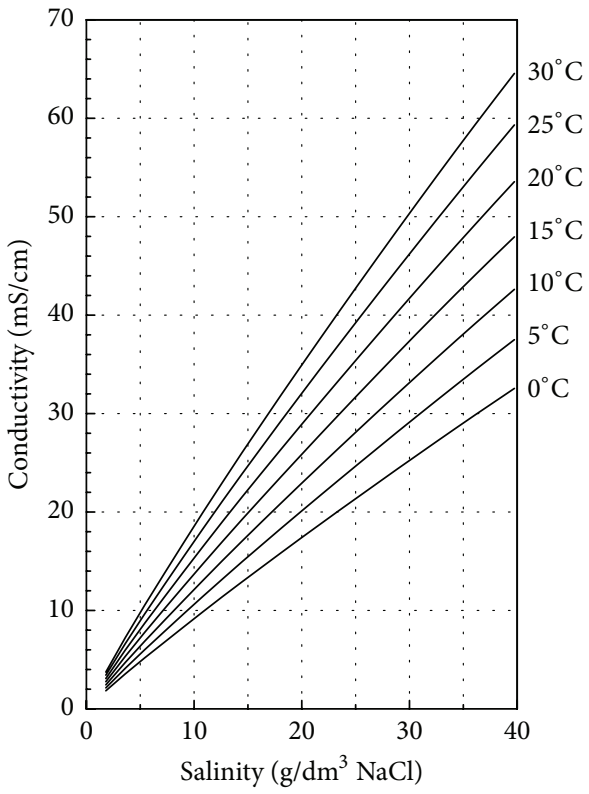

FIGURE 1: Seawater conductivity as a function of salinity and temperature, based on data in [2].

seawater temperature. Seawater conductivity as a function of salinity and temperature is shown in Figure 1. The data is taken from [2].

The nominal saturation for dissolved oxygen (DO) in seawater is about $6-8 \mathrm{ppm}$ at $25-30^{\circ} \mathrm{C}$. However, the DO may go as high as $14 \mathrm{ppm}$, depending upon wave action and seawater temperature, and supersaturation may occur due to photosynthesis. The dissolved oxygen may decrease to practically zero due to bacterial action or biological or chemical oxygen demand. Stagnant bottom waters often contains less oxygen than surface waters where there is turbulence. Oxygen solubility increases with lower temperature and lower salinity. Cold, low-salinity water can dissolve two times more oxygen than warm ocean seawater. Oxygen concentration can be

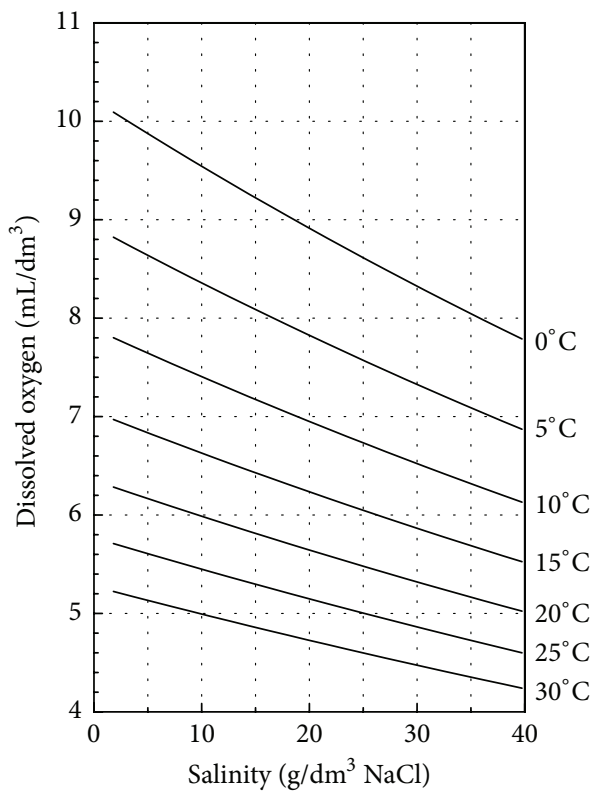

FIGURE 2: Seawater dissolved oxygen as a function of salinity and temperature calculated using (1) [1].

estimated using (1) [1]. Oxygen concentrations calculated from (1) are shown in Figure 2:

$$
\begin{aligned}
& \ln \mathrm{O}_{2}[\mathrm{~mL} / \mathrm{L}]=-173.4292+249.6339 \cdot\left(\frac{100}{T}\right) \\
& +143.3483 \cdot \ln \left(\frac{T}{100}\right)-21.8492 \cdot\left(\frac{T}{100}\right)+S \\
& \cdot\left[-0.033096+0.014259 \cdot\left(\frac{T}{100}\right)-0.0017\right. \\
& \left.\quad\left(\frac{T}{100}\right)^{2}\right] .
\end{aligned}
$$


Temperature extremes may vary from $2-4^{\circ} \mathrm{C}$ in the polar regions to $32^{\circ} \mathrm{C}$ or more in shallow waters in the tropics. The $\mathrm{pH}$ of seawater is usually in the range from 7.7 to 8.3 in surface waters due to the buffering effects of carbonate salts. More acidic conditions can be found in deep water, with $\mathrm{pH}$ 3-4 due to bacterial action. Hydrocarbons and oxygenated organic compounds produce carbon dioxide and water upon oxidation lowering the $\mathrm{pH}$ to about 5-6. On the other hand, plants consume carbon dioxide by photosynthesis, raising the $\mathrm{pH}$. Decomposing nitrogenous organic material will form amines and ammonia, tending to increase the $\mathrm{pH}$.

In this paper, we report results of long-term corrosion tests of different metals in brackish seawater. We show that the short time laboratory tests do not describe accurately corrosion rates. The difference is not always in the reproduction of natural conditions but in the typical variations of instantaneous corrosion rates as compared to long-term changes. Laboratory tests are more suitable for evaluating the effect of different factors whereas long-term tests give the information that should be used as baseline for service life estimations.

\section{Materials and Methodology}

Laboratory tests are usually done for rapid screening. In some cases, long-term tests in artificial environments are useful to monitor changes in corrosion rate with respect to time. In the laboratory, the test systems are usually common threeelectrode cells. Tests are done with computer-controlled potentiostats made by Princeton Applied Research, EcoChemie, and ACM Instruments. Test methods include polarization curves, cyclic polarization curves, potentiostatic and galvanostatic experiments, cyclic voltammetry, and electrochemical impedance spectroscopy. The experimental set-ups and equipment are well known. The electrochemical and immersion tests follow typically standards as follows:

(i) ASTM G5 Standard Reference Test Method for Making Potentiodynamic Anodic Polarization Measurements and ISO 17475 Corrosion of metals and alloyselectrochemical test methods-guidelines for conducting potentiostatic and potentiodynamic polarization measurements.

(ii) ASTM G31 Standard Guide for Laboratory Immersion Corrosion Testing of Metals.

(iii) ASTM G52 Standard Practice for Exposing and Evaluating Metals and Alloys in Surface Seawater.

(iv) ASTM G59 Standard Test Method for Conducting Potentiodynamic Polarization Resistance Measurements.

(v) ASTM G61 Standard Test Method for Conducting Cyclic Potentiodynamic Polarization Measurements for Localized Corrosion Susceptibility of Iron-, Nickel-, or Cobalt-Based Alloys and ISO 15158 Corrosion of metals and alloys-method of measuring the pitting potential for stainless steel by potentiodynamic control in sodium chloride solution. (vi) ASTM G71 Standard Guide for Conducting and Evaluating Galvanic Corrosion Tests in Electrolytes.

(vii) ASTM G78 Standard Guide for Crevice Corrosion Testing of Iron-Based and Nickel-Based Stainless Alloys in Seawater and Other Chloride-Containing Aqueous Environments and ISO 11306 Corrosion of metals and alloys-guidelines for exposing and evaluating metals and alloys in surface seawater.

(viii) ASTM G82 Standard Guide for Development and Use of a Galvanic Series for Predicting Galvanic Corrosion Performance.

(ix) ASTM G102 Standard Practice for Calculation of Corrosion Rates and Related Information from Electrochemical Measurements.

(x) ISO 8407 Corrosion of metals and alloys-removal of corrosion products from corrosion test specimens.

When working with marine applications, one specific point is test solution. In laboratory experiments, we have used $\mathrm{NaCl}$ solution, artificial seawater, and natural seawater. Selection of the test solution is based on wanted results. For some preliminary screening and for some comparison purposes, straight $\mathrm{NaCl}$ solutions are good enough. Synthetic seawater recipes are given, for example, in standard ASTM D1141, older versions of DIN 50900, and DIN EN ISO 10253. The compositions of some artificial seawater we have used are given in Table 2. To make brackish water of these synthetic ocean waters, it is necessary just to dilute wanted salinity. To make brackish water with salinity corresponding to that of Gulf of Finland, the dilution is 1:6 [4].

Testing of materials under marine atmospheric and immersion conditions is done at Isosaari marine corrosion test station. The island of Isosaari is located about 4 nautical miles southeast from Helsinki. The island has been under the command of the Defence Forces and therefore under continuous monitoring. The test station is a former torpedotesting complex, not used since the 1940s. The immersion test facilities are inside the building. Large scale test racks are in the $6 \times 15 \mathrm{~m}, 5 \mathrm{~m}$ deep shooting chamber with constant access to the sea $2 \mathrm{~m}$ below the surface. The chamber faces south to the open sea. Small tests are done in seawater circulation loop, which draws water from the shooting chamber. The seawater is brackish water with low salt concentration. Its temperature varies through the year from about $0^{\circ} \mathrm{C}$ in January to 15 $16^{\circ} \mathrm{C}$ in June-August. Salinity is $4-6 \%$, highest at the end of summer and lowest when ice melts. $\mathrm{pH}$ is between 7.0 and 8.1.

A planned interval immersion test according to the standard DIN 50917 was done 1999-2003 to produce baseline corrosion rates for different materials in Gulf of Finland brackish water. The materials were $99.5 \%$ aluminium, $99.5 \%$ copper, brass CuZn23All, unalloyed steel, stainless steel types AISI 304L and AISI 316L, 99.995\% zinc, and hot dip galvanized steel plate. The samples were $10 \times 10 \mathrm{~cm}$ plates with a thickness of $1-2 \mathrm{~mm}$. Figure 3 shows the test rack and a PVC base plate on which the samples are fixed. There were four 1-year tests, two 2-year tests, and one 4-year test. Every test set contained five samples of each test material. There were all the time three sets in the test. The samples were 
TABLE 2: Composition of some artificial seawater samples.

\begin{tabular}{|c|c|c|c|c|}
\hline Chemical & $\begin{array}{c}\text { Type I } \\
\text { Amount [g] }\end{array}$ & $\begin{array}{c}\text { Type II } \\
\text { Amount }[\mathrm{g}]\end{array}$ & $\begin{array}{c}\text { Type III } \\
\text { Amount [g] }\end{array}$ & $\begin{array}{c}\text { Type IV } \\
\text { Amount [g] }\end{array}$ \\
\hline $\mathrm{NaCl}$ & 28 & 22 & 24.53 & 32.0 \\
\hline $\mathrm{Na}_{2} \mathrm{SO}_{4}$ & & 3.7 & 4.09 & \\
\hline $\mathrm{MgSO}_{4} \cdot 7 \mathrm{H}_{2} \mathrm{O}$ & 7 & & & 14.0 \\
\hline $\mathrm{MgCl}_{2} \cdot 6 \mathrm{H}_{2} \mathrm{O}$ & 5 & 9.7 & 5.20 & \\
\hline $\mathrm{CaCl}_{2} \cdot 6 \mathrm{H}_{2} \mathrm{O}$ & 2.4 & & & \\
\hline $\mathrm{CaCl}_{2}$ & & 1.0 & 1.16 & \\
\hline $\mathrm{KCl}$ & & 0.65 & 0.695 & \\
\hline $\mathrm{KBr}$ & & & 0.10 & \\
\hline $\mathrm{NaHCO}_{3}$ & 0.2 & 0.20 & 0.20 & 0.20 \\
\hline $\mathrm{H}_{3} \mathrm{BO}_{3}$ & & 0.027 & 0.027 & \\
\hline $\mathrm{H}_{2} \mathrm{O}$ & 985 & To make $1 \mathrm{dm}^{3}$ & To make $1 \mathrm{dm}^{3}$ & $\begin{array}{l}\text { To make } \\
1 \mathrm{dm}^{3}\end{array}$ \\
\hline
\end{tabular}
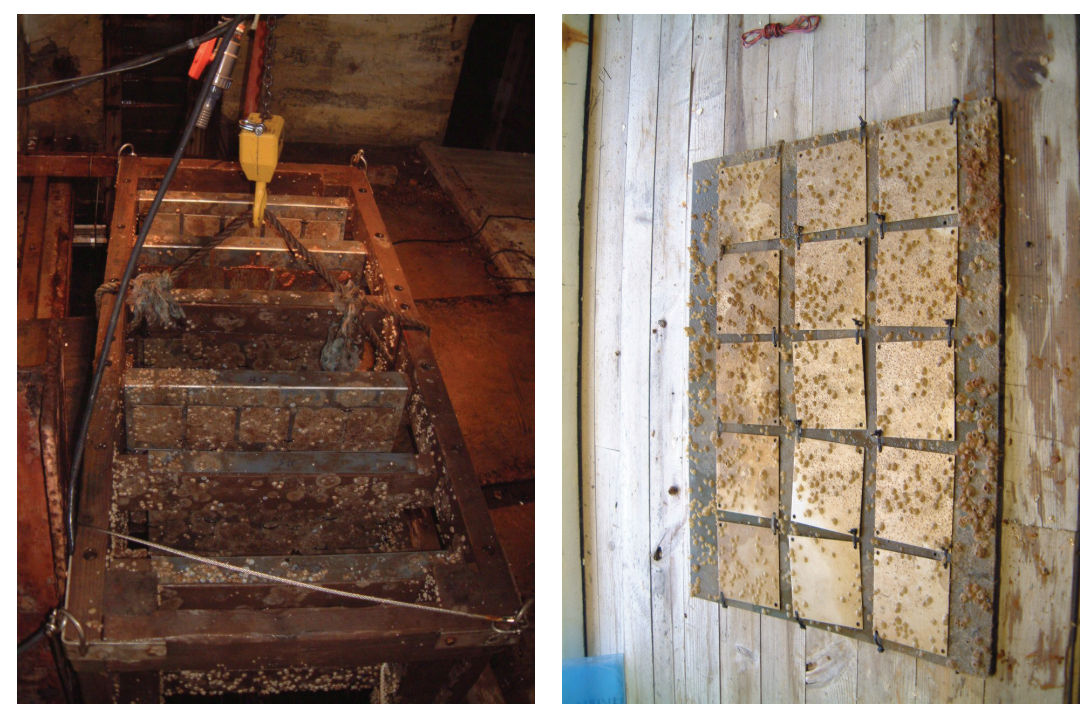

FIGURE 3: Test arrangement for planned interval immersion test, the test rack for all eight materials, and PVC back plate with AISI 304 type stainless steel samples.

installed and removed always in November. The test duration was 350-390 days for 1-year tests, 727 and 740 days for 2-year tests, and 1427 days for 4-year tests. The samples were cleaned mechanically and chemically, but all barnacle remains could not be removed from every sample.

Pitting and crevice corrosion tests have been done with and without crevice formers. Figure 4 shows an example of crevice corrosion testing. The tests have been done within the European Federation of Corrosion Test Program Comparison of Seawater Corrosivity in Europe. The crevice corrosion testing including three different austenitic stainless steel types was UNS S31254, UNS S31600, and UNS N08904. The test specimens had dimensions of $300 \times 200 \times 2-3 \mathrm{~mm}$. The materials were delivered cold-rolled and pickled and used as-received. The crevice formers were made of POM (polyoxymethylenechloride) rings in combination with UNS 31254 stainless steel bolts, nuts, and locking rings. The POM ring surfaces were ground with a grade $500 \mathrm{SiC}$ paper.
The POM rings were pressed against the test specimen with a torque of $3 \mathrm{Nm}$ [5].

To estimate steel corrosion effect on strength and ductility sandwich, panels were manufactured using two different geometries typical in industrial applications, Figure 5. The panels were corrugated core and the web-core sandwich beams. Web-core sandwich beam nominal material thicknesses were $4 \mathrm{~mm}$ for the inner plates and $2.5 \mathrm{~mm}$ for the face plates. Corrugated core sandwich beam nominal plate thickness was $2 \mathrm{~mm}$ for all parts. The samples were immersed for one- and two-year periods. After testing, the corrosion rates were determined by measuring thicknesses from the ends and special attention was paid to corrosion of welds and joint crevices. The corroded panels were subjected to mechanical testing to estimate loss of strength. The material stress-strain curves were determined by tensile testing on $200 \mathrm{~mm}$ tensile specimens with test length $75 \mathrm{~mm}$ or $76.5 \mathrm{~mm}$. The specimens were cut from beams after the ultimate strength experiments 

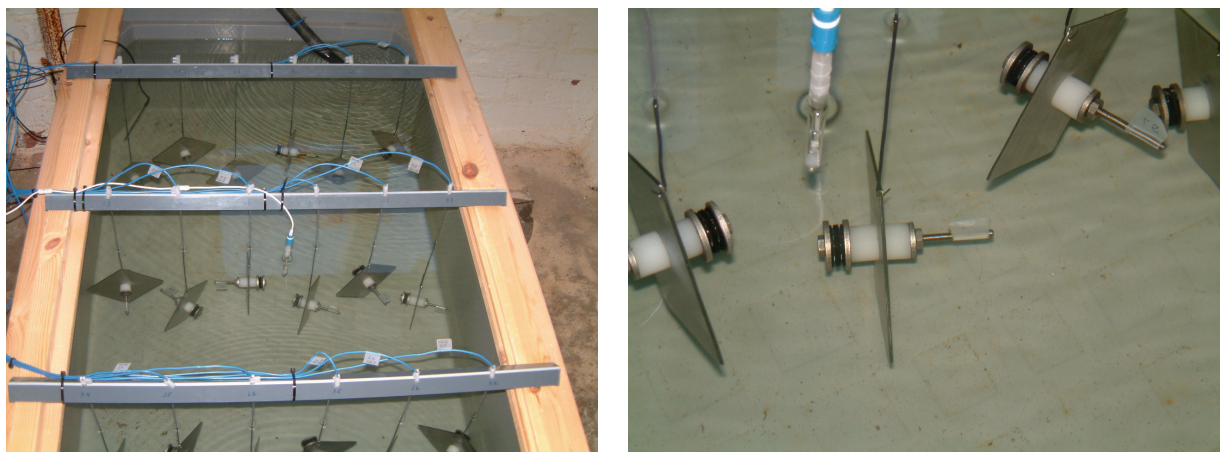

Figure 4: Test setup for crevice corrosion testing in seawater corrosivity comparison test series.

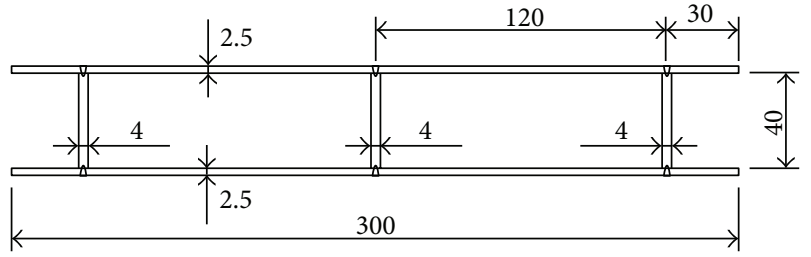

(a)

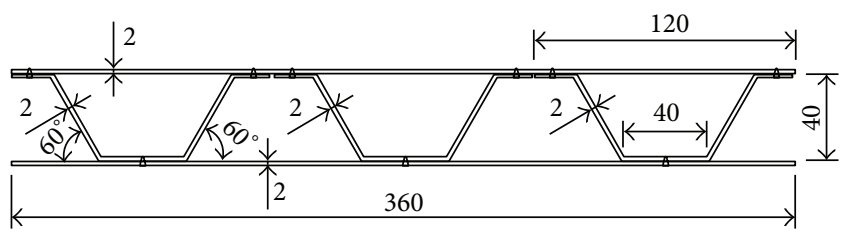

(b)

FIGURE 5: The cross-sectional dimensions for web-core sandwich beam (a) and corrugated core sandwich beam (b) [3].

from the locations that were only elastically deformed. The tests were performed with $30 \mathrm{kN}$ force capacity for the specimens of $2 \mathrm{~mm}$ and $2.5 \mathrm{~mm}$ nominal thickness and $100 \mathrm{kN}$ force capacity for the $4 \mathrm{~mm}$ specimens. The elongation speed in experiments was $1.2 \mathrm{~mm} / \mathrm{min}$ [3].

\section{Results}

Corrosion rates have measured in the laboratory using weight loss tests and polarization resistance measurements (LPR), electrochemical impedance spectroscopy (EIS), and polarization curves. Electrochemical tests give often a higher corrosion rate than weight loss tests. This is due to short times; the sample is allowed to develop a corrosion product layer that will affect the corrosion rate. With longer exposure times, the corrosion rates measured by electrochemical methods will usually decrease. In long-term tests, when test times are, for example, weeks, the preferred methods are LPR and EIS that will not change the sample surface. Table 3 presents corrosion rates determined in the laboratory for unalloyed steel and AISI 316L type stainless steel. Strong variation is seen in the general corrosion rates of unalloyed steel depending on environment and method, but not for stainless steel.
Laboratory tests can be used to measure the effect of different factors that affect corrosion rate but are difficult to control in the field tests. For example, the solubility of oxygen increases with decreasing temperature and salinity. Cold, low-salinity water can dissolve two times more oxygen than warm ocean seawater. Standard SFS-EN 13173 Cathodic protection for steel offshore floating structures lists five geographical areas. In areas with moderate temperature and high salinity, such as Mediterranean Sea and Gulf of Mexico, the current demand is $50 \%-60 \%$ of that in cold water. The effect of salinity and flow rate on protection current density was studied by measuring cathodic polarization curves with rotating disk electrode. Tests were done in synthetic seawaters of different salinities. Figure 6 shows cathodic polarization curves at two rotating speeds for three synthetic seawater samples. Increase in rotating speed shifts the corrosion potential to more noble values and increases the limiting current density of oxygen reduction reaction. Based on the limiting current density values, the current demand for a moving vessel can be ten times higher than for stationary vessel $[6,7]$. The current demand is higher for low-salinity water for stationary systems, but already at relatively low flow rate the cathodic reaction rates are the same. Figure 7 shows measured polarization resistance values at different rotating speeds. The salinity does not seem to have large influence on polarization resistance. The rotating speed has clearly an effect, and the stationary system polarization resistance values are 6-10 times higher than those at high rotation speeds.

Results of the interval tests at the Isosaari marine corrosion test station are shown in Figures 8 and 9. Figure 8 shows loss of thickness calculated using weight loss for four successive 1-year tests. Figure 9 shows the effect of test length on corrosion rates during immersion tests. Generally, it is expected that the corrosion rate will decrease with time. In this case, the effect was seen clearly with aluminium, copper, and zinc and less clearly with steel. The immersion test results have been used as baseline in all our marine corrosion tests. Corrosion rates are shown in Table 4 . The results in Table 4 show that corrosion rate of unalloyed steel is close to the average value of $110 \mu \mathrm{m} /$ year [2]. Corrosion rate of zinc is the same $50 \mu \mathrm{m} /$ year given in [2]. Galvanized steel shows some corrosion of zinc coating. Corrosion rates of other materials 
TABLE 3: Corrosion rates for unalloyed steel and AISI 316L type stainless steel.

\begin{tabular}{|c|c|c|c|}
\hline Material & Environment & Method & Rate, $\mu \mathrm{m} /$ year \\
\hline Steel & Type I water, $0^{\circ} \mathrm{C}$ & Corrosion current by Tafel method & 58 \\
\hline Steel & Type I water, $10^{\circ} \mathrm{C}$ & Corrosion current by Tafel method & 93 \\
\hline Steel & Type I water, $20^{\circ} \mathrm{C}$ & Corrosion current by Tafel method & 180 \\
\hline Steel & Type I water, $0^{\circ} \mathrm{C}$, diluted $1: 6$ & Corrosion current by Tafel method & 46 \\
\hline Steel & Type I water, $10^{\circ} \mathrm{C}$, diluted $1: 6$ & Corrosion current by Tafel method & 60 \\
\hline Steel & $3.5 \% \mathrm{NaCl}, 20^{\circ} \mathrm{C}, 14$-day test & Corrosion current by LPR & 280 \\
\hline Steel & $3.5 \% \mathrm{NaCl}, 20^{\circ} \mathrm{C}, 28$-day test & Corrosion current by LPR & 310 \\
\hline Steel & $3.5 \% \mathrm{NaCl}, 20^{\circ} \mathrm{C}, 14$-day test & Weight loss & 70 \\
\hline Steel & $3.5 \% \mathrm{NaCl}, 20^{\circ} \mathrm{C}, 28$-day test & Weight loss & 52 \\
\hline AISI 316L & Type I water, $0^{\circ} \mathrm{C}$ & Corrosion current by Tafel method & $<2$ \\
\hline AISI 316L & Type I water, $10^{\circ} \mathrm{C}$ & Corrosion current by Tafel method & $<2$ \\
\hline AISI 316L & Type I water, $0^{\circ} \mathrm{C}$, diluted $1: 6$ & Corrosion current by Tafel method & $<2$ \\
\hline AISI 316L & Type I water, $10^{\circ} \mathrm{C}$, diluted $1: 6$ & Corrosion current by Tafel method & $<2$ \\
\hline AISI 316L & $3.5 \% \mathrm{NaCl}, 20^{\circ} \mathrm{C}$ & Corrosion current by LPR & $<1$ \\
\hline
\end{tabular}

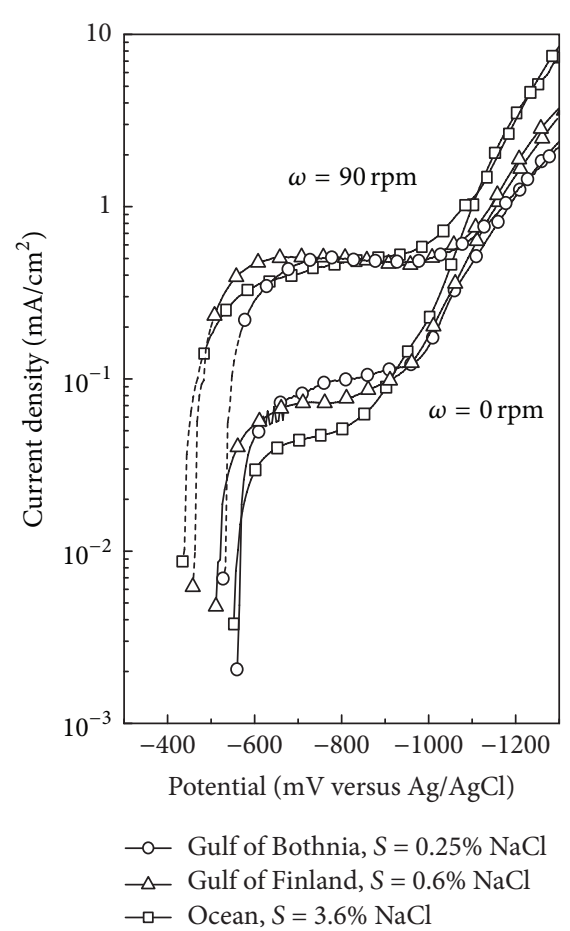

Figure 6: Cathodic polarization curves in three different Type I synthetic seawater samples of different salinity.

are small. Stainless steel showed no weight loss at all, and calculated results give even negative corrosion rates for some samples.

Pitting and crevice corrosion of stainless steel are predominantly caused by chloride ions, although other halides have a similar effect. The corrosiveness of salt solutions to metals depends on solution $\mathrm{pH}$, oxidizing versus reducing conditions, presence of halides, temperature, flow velocity, and so forth. Sulfates and carbonates are less aggressive than halides and they can even neutralize the effect of halides to some extent [8]. The Pitting Resistance Index (PRE-values)

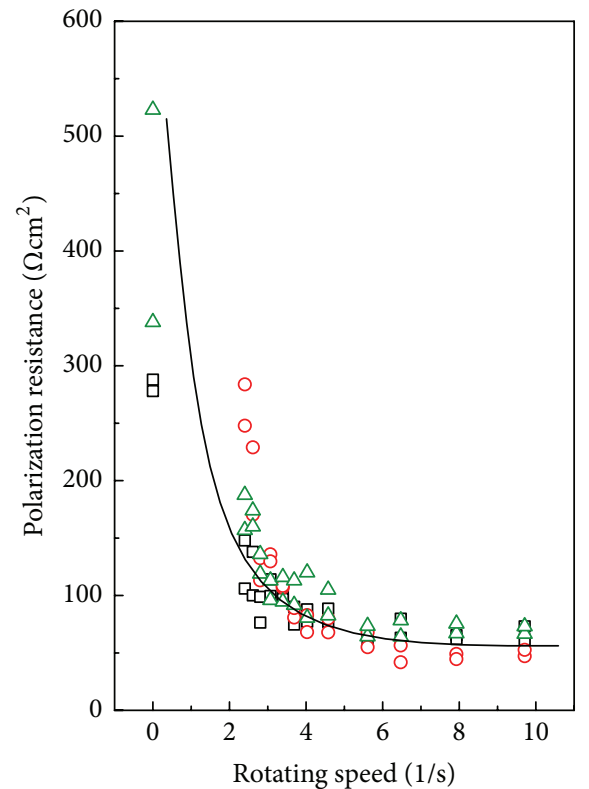

Polarization resistance as a function
of rotating speed
$\square$ Gulf of Bothnia
$\circ$ Gulf of Finland
$\triangle$ Ocean

FIGURE 7: Polarization resistance as a function of rotating speed in three Type I synthetic seawater samples of different salinity.

calculated from the composition of the steel can be used as a first estimate on the corrosion resistance. Another method is to create different kind of pass-fail charts in $\log \left[X^{-}\right]-T$ domain based on cyclic polarization tests; $\left[X^{-}\right]$is the concentration of an aggressive anion. The charts are based on the borderlines for experiments where all samples failed and no sample failed. When the pass-fail chart of a simple chloride-based solution is known, the effect of other ions can be estimated by studying the shift of the pass and fail areas. 
TABLE 4: Results of planned interval immersion test in Isosaari brackish water, average values from all tests.

\begin{tabular}{lc}
\hline Material & Corrosion rate $\mu \mathrm{m} /$ year \\
\hline Al 99.5\% & $5 \pm 1$ \\
$\mathrm{Cu}$ 99.5\% & $4 \pm 1$ \\
CuZn23All & $12 \pm 1$ \\
Unalloyed steel & $120 \pm 10$ \\
Galvanized steel & $24 \pm 3$ \\
304 stainless steel & $<1$ \\
316 stainless steel & $<1$ \\
Zn 99.995\% & $50 \pm 4$ \\
\hline
\end{tabular}

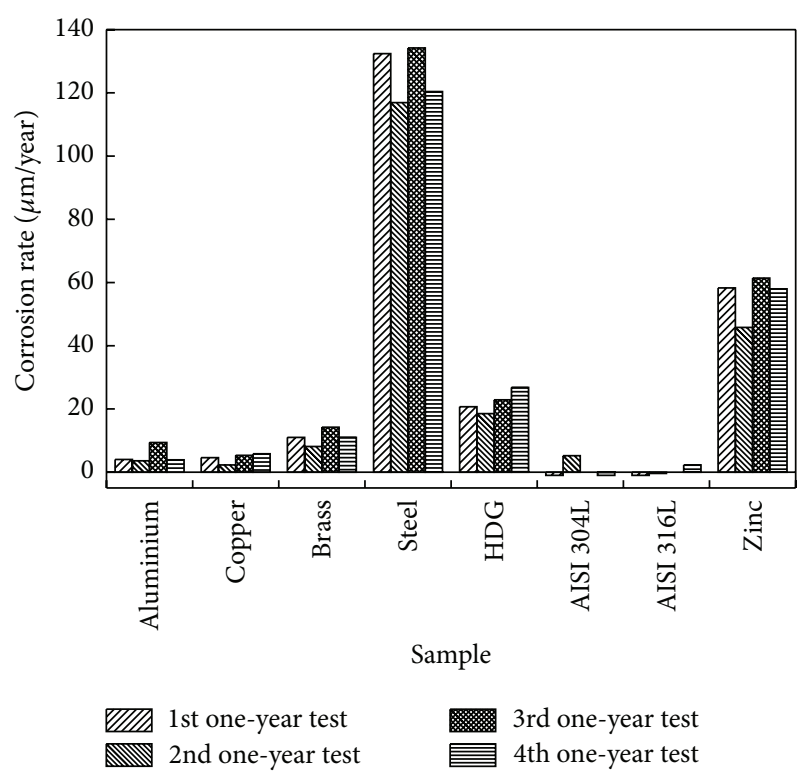

FIGURE 8: Variation of corrosion rates in immersion tests in successive 1-year tests.

The critical temperatures follow often equation of type $\log (T)=A+B \cdot \log \left[X^{-}\right][9]$. Typically the temperature decreases quite smoothly as chloride concentration increases permitting curve fitting. The effects of a more complex solution composition and temperature were studied in synthetic seawater (Type I). Test materials were UNS S31603, S32304, and S31803. The artificial seawater was diluted by distilled water in order to adjust the chloride content. The borderlines of pass areas were not continuous as in simple ammonium chloride solutions in [9]. The results in Figure 10 for austenitic steel S31603 show that at 1:100 dilution the steel is corrosion resistant up to $T=40^{\circ} \mathrm{C}$ and at higher chloride concentration the critical temperature decreases with increasing chloride concentration. The duplex steel S32304 has about the same PRE-value compared to S31603. The pass area of S32304 has two horizontal ranges at low and high chloride concentrations and a sloping transition in between.

The test results indicate that diluted seawater with equal chloride concentration is less aggressive than ammonium chloride for some stainless steel due to the inhibiting effect of other components. It is most probable that other anions are

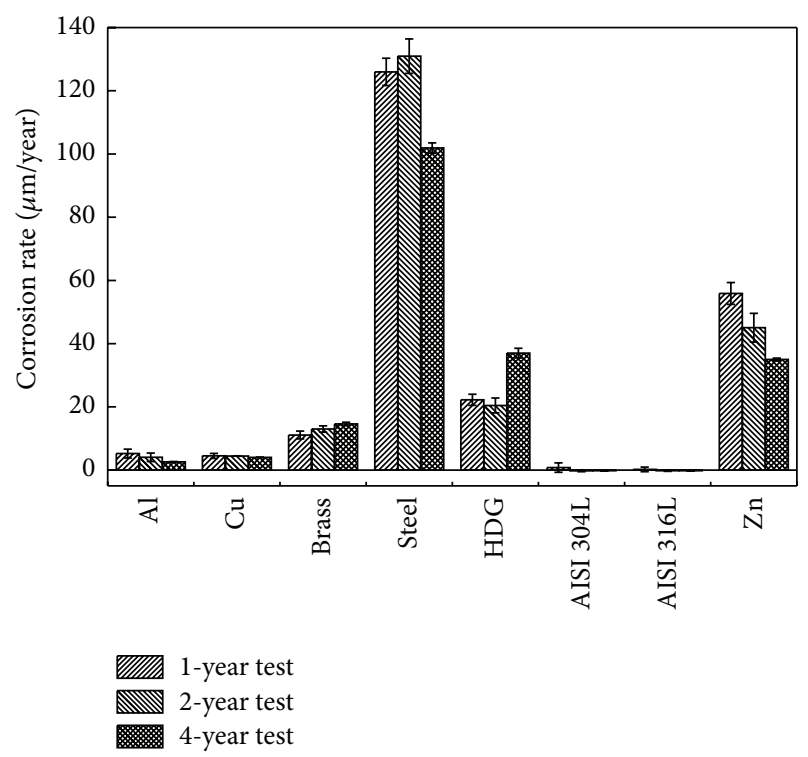

FIGURE 9: Comparison of corrosion rates in immersion tests for 1-, $2-$, and 4-year tests.

adsorbing on the passive film of stainless steel and prevent adsorption of chloride ions. For less alloyed steel, the critical pitting temperature in seawater was $5-15^{\circ} \mathrm{C}$ higher than in ammonium chloride solution with the same ppm level of chlorides. For higher alloyed duplex steel UNS S31803, the critical temperature was slightly lower in seawater than in ammonium chloride solution. Depending on steel and solution composition, either anion concentration or temperature can be the more critical factor.

When studying the effect of corrosion on strength and ductility, the sandwich beam samples were immersed in brackish water for one or two years. After taking away from the test, the beam samples were washed and loose corrosion products were removed. The samples were then subjected to ultimate strength tests. After these bending tests, $15 \mathrm{~cm}$ long pieces were cut from both ends of the beam for more thorough corrosion analysis and several tensile test specimens were cut and machined from elastically deformed parts of the beams. Corrosion rates were measured from the ends of samples, Table 5. The average corrosion rate was $0.12 \mathrm{~mm} /$ year in one-year tests and $0.10 \mathrm{~mm} /$ year in two-year tests. The corrosion rates correspond to $0.10-0.13 \mathrm{~mm} /$ year that has been measured in the baseline immersion test for unalloyed steel; see Tables 4 and 5. There was stronger variation in the corrosion rates as weight loss measurement could not be used and the loss of thickness was measured using micrometer.

Web-core and corrugated core sandwich beams were tested in three-point bending. The top face plate of each specimen buckled in the experiment. The buckles on the top face plate appeared on each specimen at about $90 \%$ of the ultimate strength. The ultimate strength of the uncorroded web-core panel was $60 \mathrm{kN}$. The strength decreased to $53 \mathrm{kN}$ and $50 \mathrm{kN}$ for the one- and two-year unprotected samples. For the corrugated core panels, the ultimate strength was 


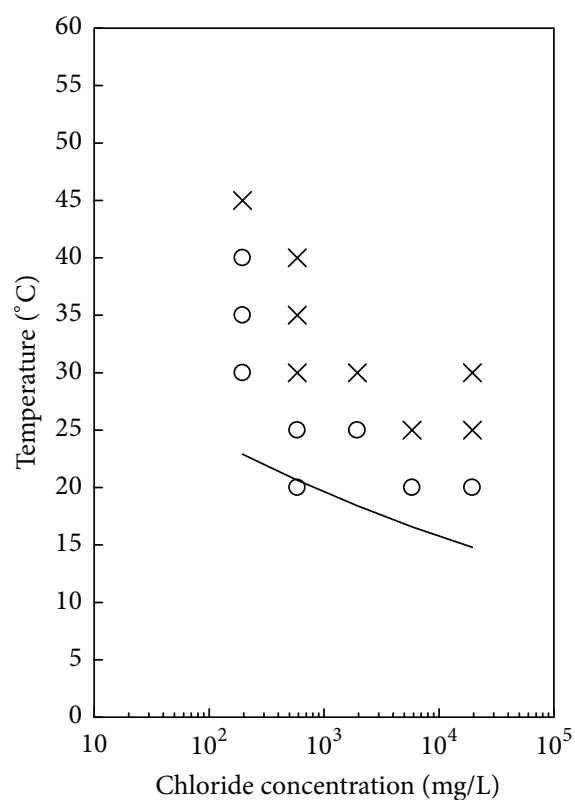

UNS S31603, synthetic seawater

$\circ$ Pass

$\times$ Fail

— Pass temperatures in $\mathrm{NH}_{4} \mathrm{Cl}$

(a)

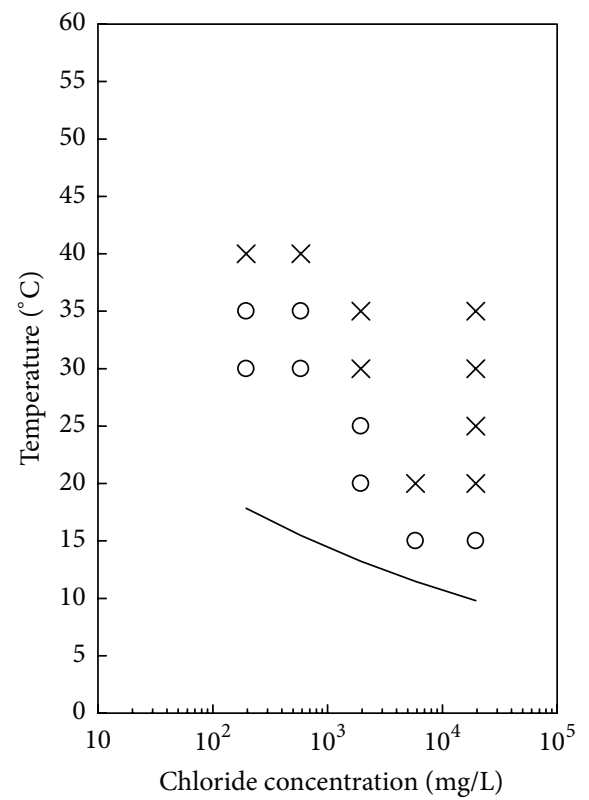

UNS S32304, synthetic seawater

○ Pass

$\times$ Fail

— Pass temperatures in $\mathrm{NH}_{4} \mathrm{Cl}$

(b)

FIgURE 10: Pass-fail chart of UNS S31603 and S32304 in Type I synthetic seawater.

TABLE 5: Corrosion rates of unprotected samples after 1 and 2 years.

\begin{tabular}{lcc}
\hline Sample & $\begin{array}{c}\text { 1-year tests, } \\
\text { mm/year }\end{array}$ & $\begin{array}{c}\text { 2-year tests, } \\
\text { mm/year }\end{array}$ \\
\hline Corrugated core, face plate & $0.09 \pm 0.01$ & $0.09 \pm 0.01$ \\
Corrugated core, inner plate & $0.13 \pm 0.01$ & $0.09 \pm 0.01$ \\
Web-core, face plate & $0.15 \pm 0.01$ & $0.10 \pm 0.01$ \\
Web-core, inner plate & $0.13 \pm 0.01$ & $0.10 \pm 0.01$ \\
\hline
\end{tabular}

$57 \mathrm{kN}$ for the uncorroded specimens. The one-year unprotected corroded panel had ultimate strength $50 \mathrm{kN}$ and those of the two-year corroded specimens were $48 \mathrm{kN}$ and $40 \mathrm{kN}$. The reduction in ultimate strength of unprotected web-core beams was $14.5 \%$ and $17 \%$ for one- and two-year corroded samples. For the corrugated core beams, the reduction was $10 \%$ and $16 \%$. The stress-strain behaviour of the beam's plates was determined with tensile tests. The stress-strain curves from corroded tensile specimens were untypical. The ductility was reduced and the material started to strain harden immediately after the onset of yielding. Yield and ultimate strength did not change during immersion when loss of thickness was taken into account.

\section{Discussion}

Cold brackish water is expected to be more corrosive than warm ocean water. This is based on the theoretical model of corrosion cell and mixed potential theory, where the rate of cathodic reaction determines the corrosion rate. In seawater, the main cathodic reaction is oxygen reduction. As the solubility of oxygen is higher in cold, low-salinity water, the rate of cathodic reaction and thus corrosion is expected to be higher. This is supported by the design values of cathodic protection systems.

Generally, the corrosion rates in seawater have been documented in many publications, for example, in [2]. It is noted that the variations in corrosion rates can be explained by the local environment, length of exposure, and method to determine the corrosion effect. Also the form of corrosion affects the determination of corrosion rate. For example, aluminium and stainless steel are passivating metals, so their corrosion is usually not general corrosion but pitting or crevice corrosion and thus weight loss results converted to loss of thickness can result in too low corrosion rates. Pit depth would be more appropriate estimate of corrosion rate.

Marine corrosion testing is done in laboratory and field. The selections of test methods and environments depend on the information wanted. In most cases, simple synthetic seawater is suitable for corrosion studies in the laboratory. The effect of biological activity can be taken into account with suitable additives [10]. Comparison of laboratory and field tests shows that variation corrosion rates determined in laboratory tests can be much higher than those of field tests. Even though the conditions in the laboratory are better controlled, the short exposure times and small sample sizes can cause variation. Also the different electrochemical methods used in the laboratory can cause variation during 
analysis and this can depend on the person or the software doing curve fitting and so forth.

The interval immersion test done in natural seawater over four-year period has given a good baseline for general corrosion rates. When comparing the long-term results with published results, it is noted that the corrosion rates of unalloyed steel, CuZn23All brass, galvanized steel, and zinc correspond to the average rates given in [2]. The corrosion rate of aluminium is lower than the corrosion rate range in [2] and the corrosion rate of copper is on the lower range as described in [2]. The stainless steel does not show measurable corrosion at all. Pitting was not detected and the weight losses were small. As all deposits could not be removed, it is possible that any weight loss of stainless steel was masked by barnacle remains and so forth. Considering general corrosion, the cold, low-salinity water does not seem to be more corrosive than other seawater samples.

The stainless steel did not show general corrosion, pitting corrosion, or crevice corrosion. Pitting and crevice corrosion are expected to start when aggressive anion concentration or temperature is too high. In this case, the cold, low-salinity water can be less corrosive than warm ocean waters. The higher oxygen concentration is not affecting redox potential so much that localized corrosion would start; probably the higher oxygen concentration will even enhance passivation.

In the beam tests the corrosion rates were the same as in the four-year interval test. The weld seams or heat affected zones on outer surfaces had not corroded. The beams were tested in three-point bending. The ultimate strength of new unprotected web-core panel was $60 \mathrm{kN}$ and its reduction was $14.5 \%$ and $17 \%$ for one- and two-year corroded samples. The ultimate strength of new corrugated core panel was $57 \mathrm{kN}$ and reduction was $10 \%$ and $16 \%$. The stress-strain curves indicated that strain at fracture decreases with increasing corrosion testing time, although the ultimate strength remains unchanged. The ductility of the samples was reduced and strain hardening commenced from the onset of yielding. Changes in stress-strain curve are in accordance with recent findings [11, 12]. It was assumed that the ductility was reduced because of hydrogen entering the steel structure. The steel surfaces were covered by inner black and outer brown corrosion product layers. This could indicate anoxic conditions close to steel surface and possible hydrogen evolution.

\section{Conclusions}

Cold brackish water is expected to be more corrosive than warm ocean water. This is based on the theoretical model of corrosion cell and mixed potential theory, where the rate of cathodic reaction determines the corrosion rate. In seawater, the main cathodic reaction is oxygen reduction. As the solubility of oxygen is higher in cold, low-salinity water, the rate of cathodic reaction and thus corrosion is expected to be higher.

The laboratory tests showed quite high variation in corrosion rates, but also the reported corrosion rates from field tests have shown differences for three orders of magnitude, especially for passivating metals. The corrosion rates measured in long-term field test in Gulf of Finland brackish water indicated that for steel, zinc, and brass, for which general corrosion is expected to be the main form of corrosion, the corrosion rates are close to the expected average worldwide corrosion rates. For copper, also expecting to show general corrosion, the corrosion rate was in the low range of the reported corrosion rates. For the passivating metals, aluminium and stainless steel, corrosion rates were very low. This was explained by lack of general corrosion and very low or nonexistent pitting.

\section{Competing Interests}

The authors declare that there are no competing interests regarding the publication of this paper.

\section{References}

[1] S. C. Dexter, R. A. Dalrymple, and N. Kobayashi, The Marine Environment. Materials for Marine Systems and Structures, Academic Press, Boston, Mass, USA, 1988.

[2] W. Katz, Seawater, vol. 11 of DECHEMA Corrosion Handbook, Edited by G. Jänsch-Kaiser, VCH, Weinheim, Germany, 1992.

[3] J. Jelovica, J. Romanoff, S. Ehlers, and H. Remes, Ultimate Strength Tests of Corroded Web-Core and Corrugated-Core Sandwich Beams, Aalto University Publication Series SCIENCE, TECHNOLOGY, Espoo, 2011.

[4] J. Aromaa, D. Luhulima, A. Talo, and O. Forsén, "Corrosion prevention in cold brackish water," in Trends in Electrochemistry and Corrosion at the Beginning of the 21st Century, P.-L. Cabot Julia and E. Brillas Coso, Eds., pp. 823-844, Universitat de Barcelona, Barcelona, Spain, 2004.

[5] Marine Corrosion of Stainless Steels and D. Feron, "European Federation of Corrosion," Report EFC 33, IOM Communications, London, UK, 2001.

[6] S. Koivuniemi, The distribution of cathodic protection on icebreaker's hull in different parts of the Baltic Sea [M.S. thesis], Helsinki University of Technology, Espoo, Finland, 1999 (Finnish).

[7] J. Aromaa, A. Pehkonen, and O. Forsén, "Cathodic protection of ships in brackish water," Journal of Solid State Electrochemistry, vol. 10, no. 9, pp. 681-688, 2006.

[8] M. Prazak, "Pitting corrosion of stainless steel-prediction and protection," in Proceedings of the European Corrosion Congress (EUROCORR '91), pp. 361-365, Budapest, Hungary, 1991.

[9] O. Frosén, J. Aromaa, M. Tavi, and J. Virtanen, "Localized corrosion of stainless steels in ammonium chloride solutions," Materials Performance, vol. 36, no. 5, pp. 59-63, 1997.

[10] U. Kivisäkk, B. Espelid, and D. Féron, "Methodology of crevice corrosion testing for stainless steels in natural and treated seawaters," Report EFC 60, Maney Publishing, Leeds, UK, 2010.

[11] M. M. Ahmmad and Y. Sumi, "Strength and deformability of corroded steel plates under quasi-static tensile load," Journal of Marine Science and Technology, vol. 15, no. 1, pp. 1-15, 2010.

[12] M. R. Islam and Y. Sumi, "Geometrical effects on strength and deformability of corroded steel plates," in Advances in Marine Structures, C. Guedes Soares and W. Fricke, Eds., pp. 151-159, Taylor \& Francis Group, London, UK, 2011. 

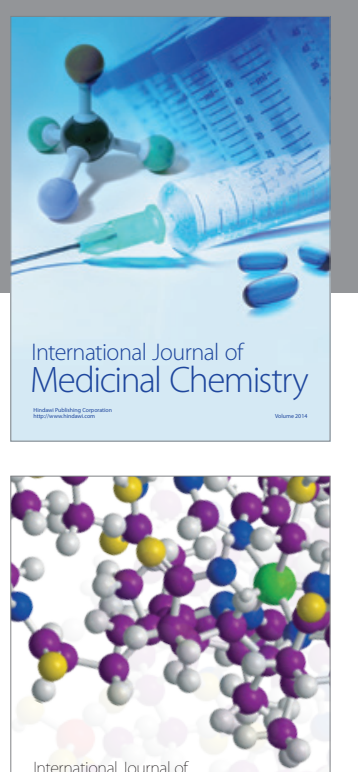

Carbohydrate Chemistry

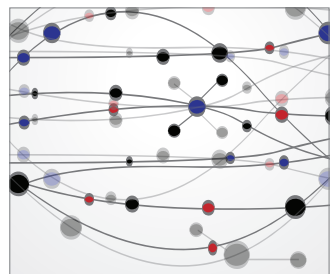

The Scientific World Journal
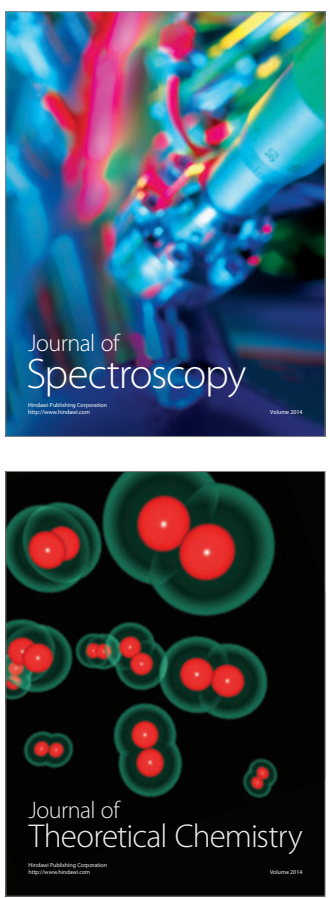
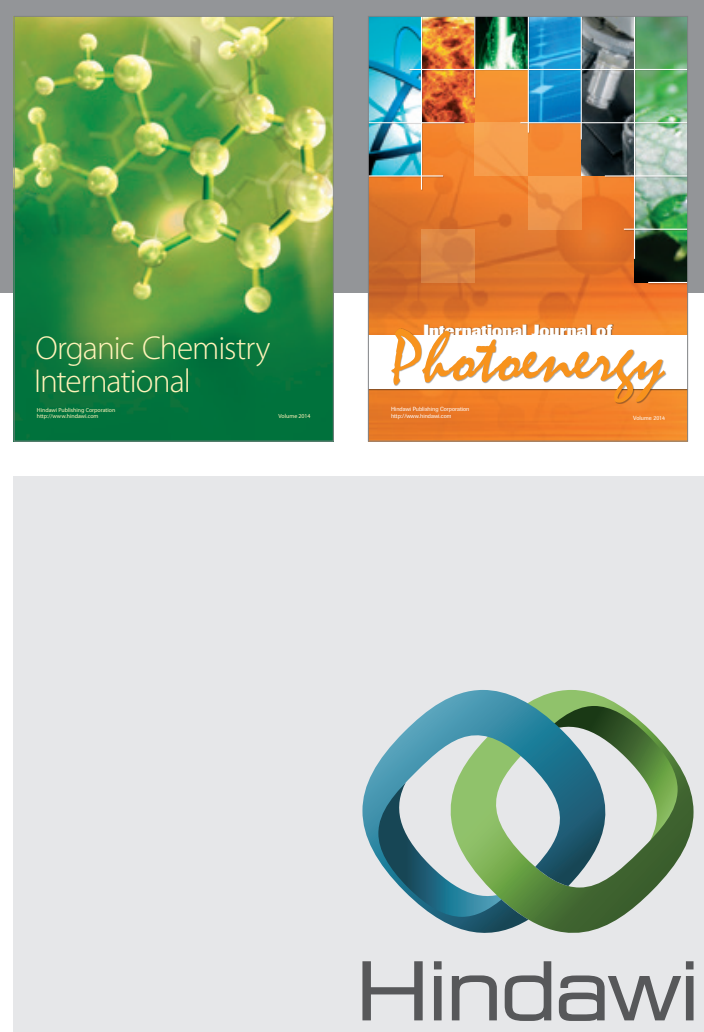

Submit your manuscripts at

http://www.hindawi.com

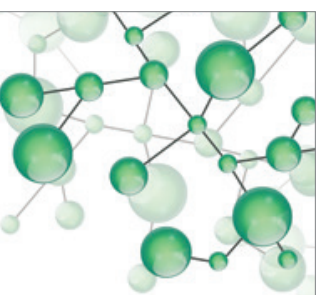

International Journal of

Inorganic Chemistry

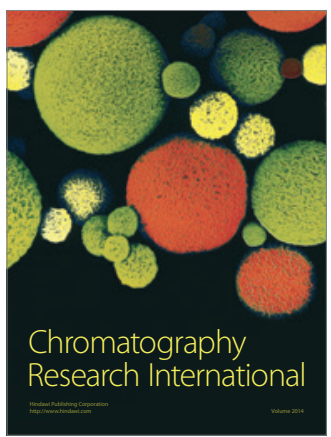

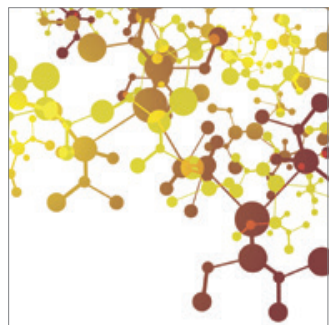

Applied Chemistry
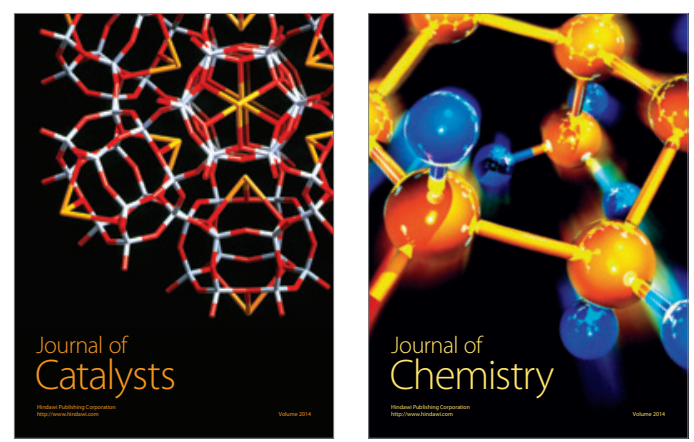
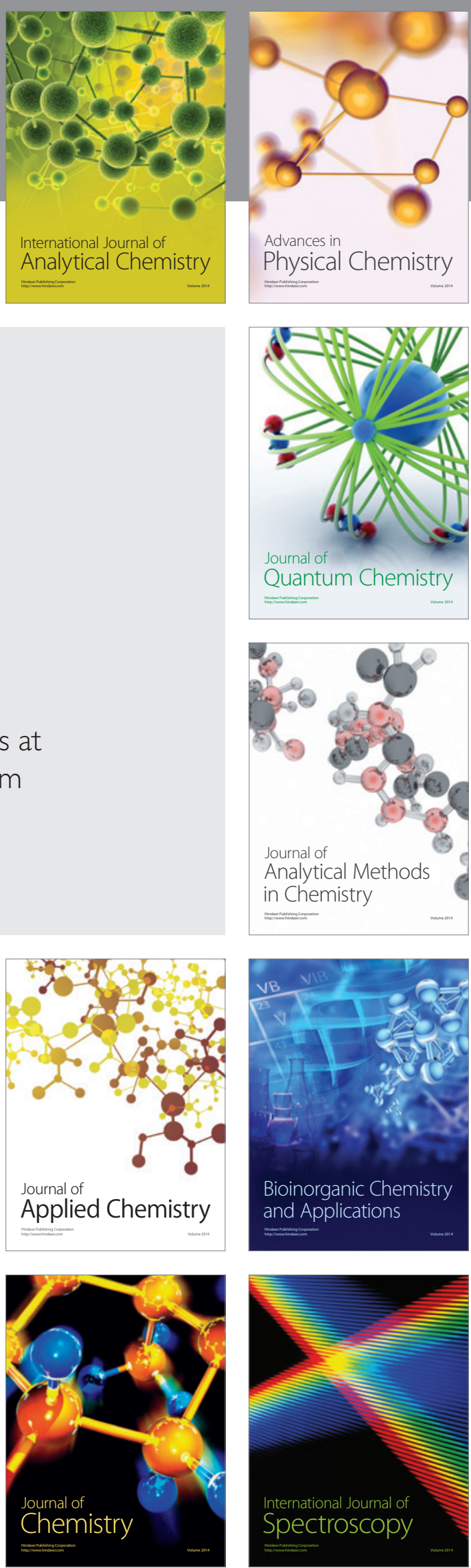